\title{
Variation in Formaldehyde Removal Efficiency among Indoor Plant Species
}

Kwang Jin Kim ${ }^{1}$, Myeong II Jeong, Dong Woo Lee, Jeong Seob Song, Hyoung Deug Kim, Eun Ha Yoo, Sun Jin Jeong, and Seung Won Han Urban Agriculture Research Division, National Institute of Horticultural and Herbal Science, Rural Development Administration, Suwon 441-440, Korea

Stanley J. Kays

Department of Horticulture, Plant Sciences Building, University of Georgia, Athens, GA 30602-7273

\section{Young-Wook Lim and Ho-Hyun Kim \\ The Institute for Environmental Research, Yonsei University, Seoul 120-752, Korea}

Additional index words. ferns, foliage plant, phytoremediation, sick building syndrome, volatile organic compounds

\begin{abstract}
The efficiency of volatile formaldehyde removal was assessed in 86 species of plants representing five general classes (ferns, woody foliage plants, herbaceous foliage plants, Korean native plants, and herbs). Phytoremediation potential was assessed by exposing the plants to gaseous formaldehyde $\left(2.0 \mu \mathrm{L} \cdot \mathrm{L}^{-1}\right)$ in airtight chambers $\left(1.0 \mathrm{~m}^{3}\right)$ constructed of inert materials and measuring the rate of removal. Osmunda japonica, Selaginella tamariscina, Davallia mariesii, Polypodium formosanum, Psidium guajava, Lavandula spp., Pteris dispar, Pteris multifida, and Pelargonium spp. were the most effective species tested, removing more than $1.87 \mu \mathrm{g} \cdot \mathrm{m}^{-3} \cdot \mathrm{cm}^{-2}$ over $5 \mathrm{~h}$. Ferns had the highest formaldehyde removal efficiency of the classes of plants tested with $O$. japonica the most effective of the 86 species (i.e., $6.64 \mu \mathrm{g} \cdot \mathrm{m}^{-3} \cdot \mathrm{cm}^{-2}$ leaf area over $5 \mathrm{~h}$ ). The most effective species in individual classes were: ferns-Osmunda japonica, Selaginella tamariscina, and Davallia mariesii; woody foliage plants-Psidium guajava, Rhapis excels, and Zamia pumila; herbaceous foliage plants-Chlorophytum bichetii, Dieffenbachia 'Marianne', Tillandsia cyanea, and Anthurium andraeanum; Korean native plants-Nandina domestica; and herbs-Lavandula spp., Pelargonium spp., and Rosmarinus officinalis. The species were separated into three general groups based on their formaldehyde removal efficiency: excellent (greater than $1.2 \mu \mathrm{g} \cdot \mathrm{m}^{-3}$ formaldehyde per $\mathrm{cm}^{2}$ of leaf area over $5 \mathrm{~h}$ ), intermediate (1.2 or less to 0.6 ), and poor (less than 0.6 ). Species classified as excellent are considered viable phytoremediation candidates for homes and offices where volatile formaldehyde is a concern.
\end{abstract}

Formaldehyde is a major contaminant in indoor air that originates from particle board, plywood, carpet, curtain, paper products, tobacco smoke, certain adhesives, and other sources (Salthammer, 1999; Spengler and Sexton, 1983). Formaldehyde concentrations in new houses are often several times higher than that in older homes (Marco et al., 1995). Indoor volatile organic compounds (VOCs) such as formaldehyde can result in "multiple chemical sensitivity" and "sick building syndrome" (Shinohara et al., 2004) and several other physical symptoms for those exposed (e.g., allergies, asthma, headaches) (Jones, 1999; Kostiaineh, 1995). The World Health Organization estimates that undesirable indoor

Received for publication 23 Feb. 2010. Accepted for publication 22 July 2010.

${ }^{1}$ To whom reprint requests should be addressed; e-mail kwangjin@korea.kr. ferences between light and dark conditions (Kil et al., 2008b). Approximately 60\% to $90 \%$ of ${ }^{14} \mathrm{C}$-formaldehyde was recovered from the plants (Giese et al., 1994; Schmitz, 1995) and it was assimilated approximately five times faster in the light than in the dark (Schmitz, 1995). Some of the formaldehyde is converted to S-methylmethionine and translocated in the phloem to various organs (e.g., seed, roots) (Hanson and Roje, 2001).

Assessing indoor plants for phytoremediation efficiency involves comparing the purification capacity among species under standard conditions. Comparing a cross-section of orchids, the formaldehyde removal efficiency of Sedirea japonicum was the highest, whereas Cymbidium spp. was the lowest of the species tested (Kim and Lee, 2008). The half-life (time required for $50 \%$ removal) is considered a good indicator of the purification capacity of a plant and allows comparing the efficiency among species under standardized conditions (Kim et al., 2008; Orwell et al., 2006; Oyabu et al., 2003). Likewise, expression of VOC removal based on leaf area allows comparing plants of varying size (Kim and Kim, 2008) and is essential for determining the number of plants needed for specific indoor environments.

Certain microorganisms found in the growing media of indoor plants are also involved in the removal of VOCs as illustrated by the fact that when the plant(s) are removed from the media, the VOC concentration continues to decrease (Godish and Guindon, 1989; Wolverton et al., 1989; Wood et al., 2002). The root zone eliminates a substantial amount of formaldehyde during both the day and night. The ratio of removal by aerial plant parts versus the root-zone was $\approx 1: 1$ during the day and 1:11 at night (Kim et al., 2008). Likewise, the removal efficiency of the media increases ( $\approx 7 \%$ to $16 \%$ ) with increased exposure frequency (Kil et al., 2008a) suggesting an apparent stimulation of the organism(s). A number of soil microorganisms are capable of degrading toxic chemicals (Darlington et al., 2000; Wolverton et al., 1989), although few of the microbes that are directly associated with formaldehyde removal has been identified.

Plants excrete into the root zone significant amounts of carbon that stimulate the development of microorganisms in the rhizosphere (Kraffczyk et al., 1984; Schwab et al., 1998). The phyllosphere is also colonized by a diverse array of microorganisms (Mercier and Lindow, 2000). Therefore, rhizospheric and phyllospheric microorganisms as well as stomatemediated absorption provide a means of biofiltration of VOCs from indoor air. As a consequence, phytoremediation of indoor air is seen as a potentially viable means of removing volatile pollutants in homes and offices (Darlington et al., 1998; Giese et al., 1994; Kempeneer et al., 2004; Kim et al., 2009; Salt et al., 1998; Wolverton et al., 1989; Wood et al., 2002). As a result of the importance of formaldehyde as an indoor air pollutant, we determined the formaldehyde removal efficiency of a diverse cross-section of indoor plants. 


\section{Materials and Methods}

Plant materials. The experiments were conducted between 2004 and 2008 at the Rural Development Administration, Suwon, Korea. The characteristics of 86 test species, classified into five general categories, are presented in Table 1. All plants were transplanted into 19or 15 -cm-diameter pots containing a uniform growing medium of Mix \#4 (Sun Gro Horti- culture, Bellevue, WA), bark-humus (Biocom. Co., Seoul, Korea), and sand at 5:1:1, v/v/v. Mix \#4 contained Canadian sphagnum peatmoss ( $55 \%$ to $65 \%$ by volume), perlite, dolomitic lime, gypsum, and a wetting agent. The plants were acclimated within the indoor environment used for the experiments for greater than 1 month $\left(23 \pm 2{ }^{\circ} \mathrm{C}, 40 \% \pm 5 \%\right.$ relative humidity). The light conditions were tailored to the plant type. Woody and herbaceous foliage plants and ferns were acclimated at a light intensity of $20 \pm 2 \mu \mathrm{mol} \cdot \mathrm{m}^{-2} \cdot \mathrm{s}^{-1}$ and the herbs and Korea native plants at $60 \pm 3 \mu \mathrm{mol} \cdot \mathrm{m}^{-2} \cdot \mathrm{s}^{-1}$; the photoperiod for all species was $12 / 12 \mathrm{~h}$ (day/night).

The plants were watered every $3 \mathrm{~d}$ with the excess water allowed to drain. All plants were watered the day before the gas treatments. One to four pots of each species were placed in a chamber. Three replicates (chambers) of every

Table 1. Indoor plant species tested and their height, leaf area, and fresh weight.

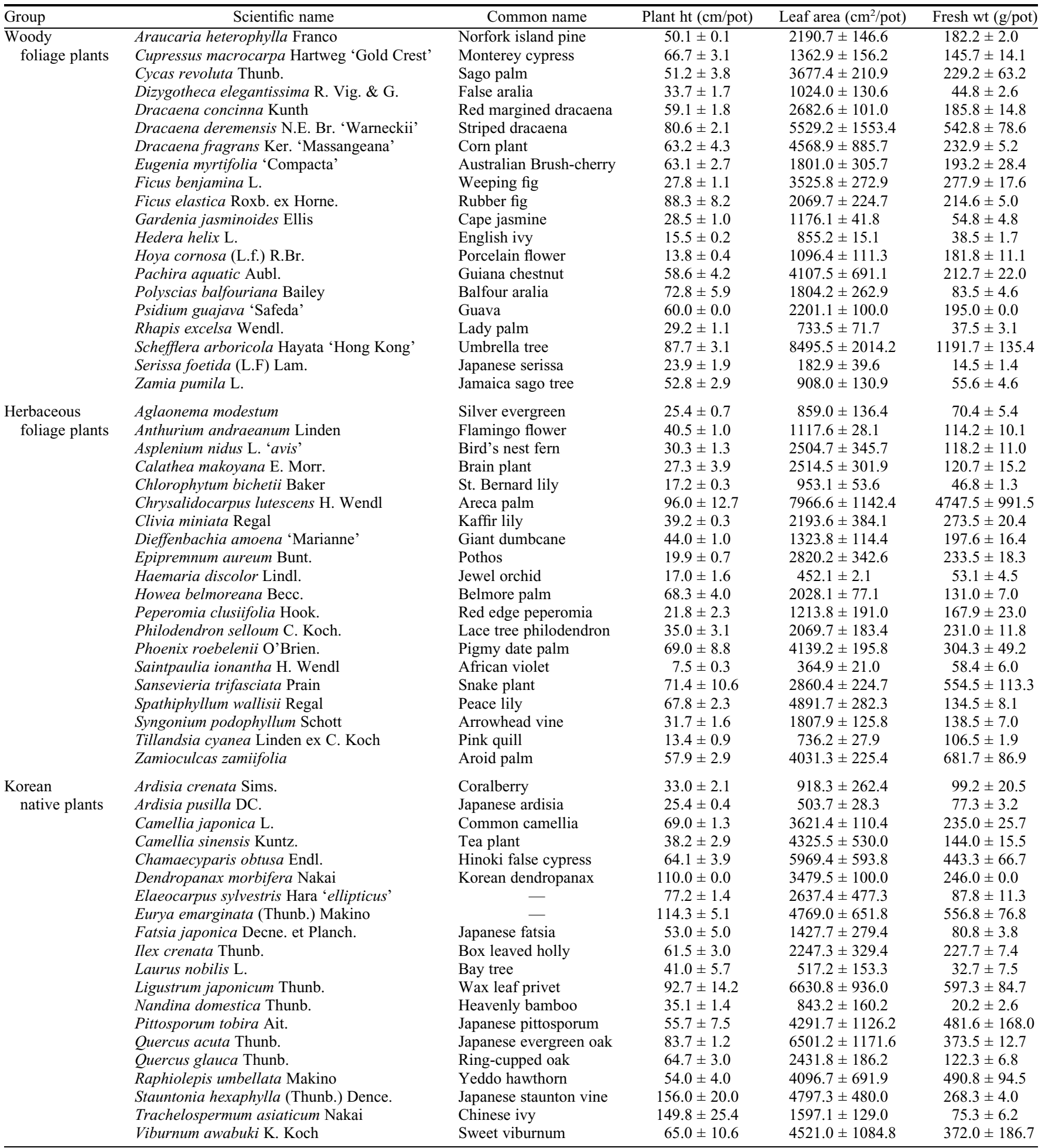


Table 1. (Continued) Indoor plant species tested and their height, leaf area, and fresh weight.

\begin{tabular}{|c|c|c|c|c|c|}
\hline Group & Scientific name & Common name & Plant ht $(\mathrm{cm} /$ pot $)$ & Leaf area $\left(\mathrm{cm}^{2} / \mathrm{pot}\right)$ & Fresh wt (g/pot) \\
\hline \multirow[t]{20}{*}{ Ferns } & Adiantum capillusveneris $\mathrm{L}$. & Southern maiden hair & $24.4 \pm 1.9$ & $811.4 \pm 33.2$ & $16.8 \pm 8.4$ \\
\hline & Arachniodes aristata (G. Forst.) Tindale & Pricky shield fern & $31.9 \pm 3.9$ & $1551.8 \pm 132.8$ & $52.1 \pm 6.0$ \\
\hline & Botrychium ternatum (Thunb.) Swartz. & Hammock fern & $16.7 \pm 1.3$ & $536.5 \pm 336.1$ & $13.0 \pm 0.8$ \\
\hline & Coniogramme japonica (Thunb.) Diels & Bamboo fern & $19.1 \pm 2.1$ & $987.8 \pm 42.7$ & $24.3 \pm 1.0$ \\
\hline & Cyrtomium caryotideum Nakai 'coreanum' & - & $20.3 \pm 0.5$ & $1997.2 \pm 250.6$ & $70.3 \pm 8.6$ \\
\hline & Cyrtomium falcatum (L.f.) Presl. & Holly fern & $50.7 \pm 6.7$ & $1107.6 \pm 69.2$ & $102.3 \pm 3.9$ \\
\hline & Davallia mariesii Moore ex Baker & Hare's-foot fern & $13.6 \pm 2.3$ & $148.9 \pm 28.1$ & $13.6 \pm 2.3$ \\
\hline & Dryopteris nipponensis Koidz. & - & $16.9 \pm 1.1$ & $734.1 \pm 41.8$ & $18.6 \pm 0.4$ \\
\hline & Microlepia strigosa (Thunb.) Presl. & Lace fern & $12.6 \pm 0.1$ & $452.9 \pm 62.2$ & $11.4 \pm 1.2$ \\
\hline & Osmunda japonica Thunb. & Japanese royal fern & $9.7 \pm 0.3$ & $95.9 \pm 14.7$ & $1.7 \pm 0.0$ \\
\hline & Polypodium formosanum Baker & - & $7.4 \pm 0.5$ & $154.9 \pm 3.7$ & $4.2 \pm 0.2$ \\
\hline & Polystichum tripteron (Kunze.) Presl. & - & $23.4 \pm 0.8$ & $825.8 \pm 235.2$ & $22.9 \pm 0.8$ \\
\hline & Pteris dispar kunze. & - & $11.4 \pm 0.3$ & $323.6 \pm 10.5$ & $11.4 \pm 0.3$ \\
\hline & Pteris ensiformis Burm. 'victoriae' & Silver leaf fern & $17.8 \pm 1.9$ & $739.8 \pm 32.3$ & $18.7 \pm 1.5$ \\
\hline & Pteris multifida Poir. & Spider fern & $34.7 \pm 1.9$ & $1338.9 \pm 225.5$ & $37.6 \pm 6.2$ \\
\hline & Selaginella tamariscina Spring & Spikemoss & $7.9 \pm 0.8$ & $143.6 \pm 21.2$ & $8.1 \pm 0.7$ \\
\hline & Thelypteris acuminate (Houtt.) Morton & - & $28.8 \pm 1.2$ & $1467.3 \pm 436.4$ & $30.9 \pm 2.2$ \\
\hline & Thelypteris decursivepinnata Ching & - & $33.8 \pm 0.4$ & $1662.6 \pm 255.4$ & $35.8 \pm 2.7$ \\
\hline & Thelypteris esquirolii K. Iwats. 'glabrata' & - & $23.1 \pm 2.6$ & $917.7 \pm 217.5$ & $17.3 \pm 2.8$ \\
\hline & Thelypteris torresiana K. Iwats. 'calvata' & - & $34.6 \pm 1.7$ & $1954.2 \pm 681.6$ & $46.7 \pm 8.3$ \\
\hline \multirow[t]{6}{*}{ Herbs } & Jasminum polyanthum Franchet & White jasmine & $113.6 \pm 6.6$ & $2216.5 \pm 343.9$ & $101.7 \pm 3.2$ \\
\hline & Jasminum sambac (L.) Aiton & Arabian jasmine & $22.1 \pm 1.4$ & $1206.6 \pm 234.2$ & $96.2 \pm 4.8$ \\
\hline & Lavandula spp. & Sweet lavender & $17.4 \pm 1.6$ & $442.7 \pm 28.8$ & $149.8 \pm 9.6$ \\
\hline & Mentha guaveolens 'applemint' & Apple mint & $18.9 \pm 1.2$ & $928.2 \pm 30.5$ & $30.8 \pm 0.2$ \\
\hline & Pelargonium spp. & Geranium & $38.7 \pm 3.6$ & $820.1 \pm 76.3$ & $77.8 \pm 7.0$ \\
\hline & Rosmarinus officinalis L. & Rosemary & $26.8 \pm 1.0$ & $678.7 \pm 38.7$ & $56.9 \pm 7.1$ \\
\hline
\end{tabular}

Data are means \pm SE $(n=9)$.

species were tested. Control chambers without plants were used to determine formaldehyde losses not resulting from the plants (e.g., leakage, adsorption, chemical reactions). Plant height and leaf area (LI-3100 area meter; LICOR Inc., Lincoln, NE) were determined at the end of the experiment (Table 1).

Treatment system. The treatment system consisted of controlled environment rooms, test chambers, and a gas generator. The environment rooms in which the test chambers were placed controlled the temperature, light intensity, and relative humidity. The test chambers were made of inert materials (i.e., glass surfaces, stainless steel frame, and Teflon) that were impermeable to VOCs. The chamber doors were sealed using an adhesive foam tape and adjustable metal clips (Fig. 1). The volume of each chamber was $1.0 \mathrm{~m}^{3}(90 \mathrm{~cm}$ wide $\times 90$ $\mathrm{cm}$ long $\times 123 \mathrm{~cm}$ high), equal to approximately half the volume of a personal breathing zone. Using a sealed external pump, the interior air was circulated $\left(6 \mathrm{~L} \cdot \mathrm{min}^{-1}\right)$ and released at the bottom of the chamber through a stainless steel tube $(0.64 \mathrm{~cm}$ i.d. $)$ with holes. The concentration of formaldehyde was determined on samples collected at three heights within the chambers (i.e., 12, 70, and $98 \mathrm{~cm}$ from a bottom of the chamber).

Gas exposure and measurement. We developed a gas generator that converted a $35 \%$ formalin solution (Katayama Chemical Co., Hygro, Japan) to gaseous formaldehyde. The gaseous formaldehyde was generated as air passed through headspace. The gaseous formaldehyde was collected in a sealed Teflon bag and $\approx 2.0 \mathrm{~L}$ was introduced into each test chamber by a quantitative pump (MP- $\Sigma$; Sibata Co., Tokyo, Japan). To compensate for the differential in air pressure, $2.0 \mathrm{~L}$ of air was removed from the chamber using a second air

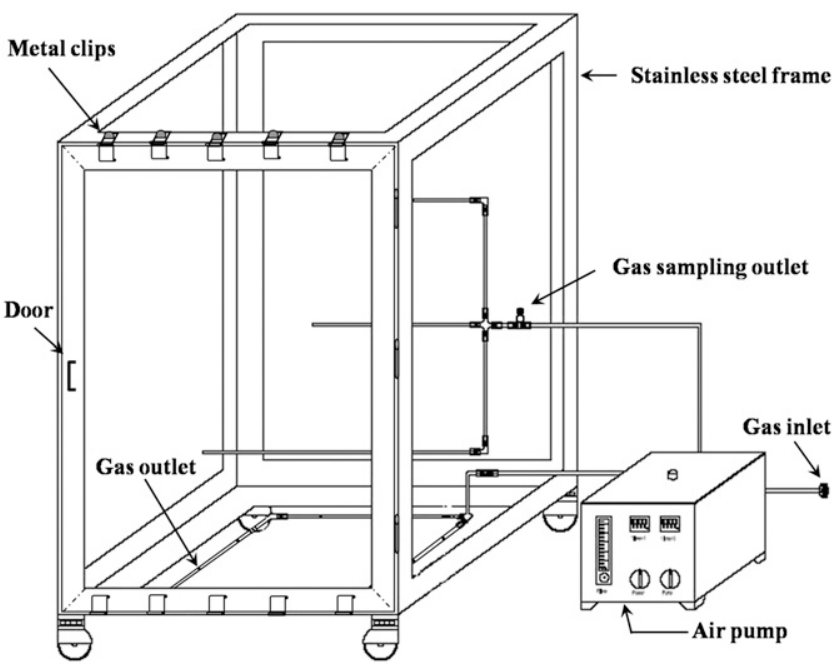

Fig. 1. Schematic diagram of one of the test chambers that were made of inert materials (i.e., glass surfaces, stainless steel frame, and Teflon) that were impermeable to volatile organic compounds (VOCs). The chamber doors were sealed using an adhesive foam-tape and adjustable metal clips. The volume of each chamber was $1.0 \mathrm{~m}^{3}(90 \mathrm{~cm}$ wide $\times 90 \mathrm{~cm}$ long $\times 123 \mathrm{~cm}$ high). Using a sealed external pump, air was circulated $\left(6 \mathrm{~L} \cdot \mathrm{min}^{-1}\right)$ and released at the bottom of the chamber through a perforated stainless steel tube $(0.64 \mathrm{~cm}$ i.d.). Gas samples were collected at three heights within the chambers (i.e., 12, 70 , and $98 \mathrm{~cm}$ from the bottom of the chamber).

pump before gas injection. The formaldehyde gas was mixed with the chamber atmosphere for 30 min using the chamber air circulation system. The internal concentration was determined and corrected to $\approx 2.0 \mu \mathrm{L} \cdot \mathrm{L}^{-1}$, a concentration that is $\approx 12 \times$ higher than that allowed in new houses in Korea (i.e., $0.17 \mu \mathrm{L} \cdot \mathrm{L}^{-1}$ ). There was a small amount of variation (e.g., 2.02 to $\left.2.30 \mu \mathrm{L} \cdot \mathrm{L}^{-1}\right)$ in the initial concentration.

The concentration of formaldehyde in the gas phase was measured using a Formaldehyde \& Data Logging System (Z300-XP; Environmental Sensors Co., Boca Raton, FL) that was calibrated to a least detectable quantity of $\approx 0.01 \mu \mathrm{L} \cdot \mathrm{L}^{-1}$. The instrument was connected to the chamber sampling tube and after stabilization for $5 \mathrm{~min}$, the concentration was determined at every hour for $5 \mathrm{~h}$ during the test. Control chambers, devoid of plants, were treated similarly to determine gas losses. The plants were exposed to the light intensity used for acclimatization during the tests.

Data analysis. Gas concentrations were expressed as $\mu \mathrm{g} \cdot \mathrm{m}^{-3}$ and the data were normalized to $24 \pm 1{ }^{\circ} \mathrm{C}$ and $100 \mathrm{kPa}$ (Hines et al., 1993). Data were expressed as the average of 
three replicates. The amount of formaldehyde removed per unit leaf area was calculated (Kim et al., 2008; Kim and Kim, 2008) as:

Formaldehyde removal $\left(\mu \mathrm{g} \cdot \mathrm{m}^{-3} \cdot \mathrm{cm}^{-2}\right.$

leaf area $)=\{[\mathrm{Pi}-(\mathrm{Ci}-\mathrm{C})]-\mathrm{P}\}$

$$
\times(\mathrm{F} \times \mathrm{CV}) / \mathrm{L}
$$

where $\mathrm{P}$ is the gas concentration measured in a chamber with plants $\left(\mu \mathrm{L} \cdot \mathrm{L}^{-1}\right)$; Pi the initial gas concentration measured in a chamber with plants $\left(\mu \mathrm{L} \cdot \mathrm{L}^{-1}\right)$; $\mathrm{C}$ the gas concentration measured in a chamber without plants $\left(\mu \mathrm{L} \cdot \mathrm{L}^{-1}\right) ; \mathrm{Ci}$ the initial gas concentration measured in a chamber without plants $\left(\mu \mathrm{L} \cdot \mathrm{L}^{-1}\right) ; \mathrm{F}$ the formaldehyde conversion factor for volume $\left(\mu \mathrm{L} \cdot \mathrm{L}^{-1}\right)$ to mass $\left(\mathrm{mg} \cdot \mathrm{m}^{-3}\right)$; $\mathrm{CV}$ the volume of the chamber $\left(\mathrm{m}^{3}\right)$; and $\mathrm{L}$ the total leaf area per chamber $\left(\mathrm{cm}^{2}\right)$.

The loss of formaldehyde $(\mathrm{Ci}-\mathrm{C})$ not resulting from the plant and media was determined using empty chambers. Data were subjected to analysis of variance using standard statistical software (SAS Institute Inc., Cary, NC) and Fisher's protected least significant difference $(\alpha \leq 0.05)$.

\section{Results and Discussion}

Among the 86 species tested, nine $(O s$ munda japonica, Selaginella tamariscina, Davallia mariesii, Polypodium formosanum, Psidium guajava, Lavandula spp., Pteris dispar, Pteris multifida, and Pelargonium spp.) displayed excellent formaldehyde removal characteristics (e.g., $1.87 \mu \mathrm{g} \cdot \mathrm{m}^{-3} \cdot \mathrm{cm}^{-2}$ or greater leaf area over $5 \mathrm{~h}$ ). In contrast, the average formaldehyde removal among all of the species tested was only $1.0 \mu \mathrm{g} \cdot \mathrm{m}^{-3} \cdot \mathrm{cm}^{-2}$ leaf area over $5 \mathrm{~h}$ or $0.20 \mu \mathrm{g} \cdot \mathrm{m}^{-3} \cdot \mathrm{h}^{-1} \cdot \mathrm{cm}^{-2}$ (Fig. 2).

P. guajava, Rhapis excels, Zamia pumila, Dizygotheca elegantissima, Ficus elastica, and Gardenia jasminoides were among the most effective formaldehyde-removing woody foliage plants (Table 2). P. guajava was the highest, whereas Dracaena deremensis 'Warneckii' was the lowest in removal efficiency. $P$. guajava removed $2.39 \mu \mathrm{g} \cdot \mathrm{m}^{-3} \cdot \mathrm{cm}^{-2}$ leaf area, $18 \times$ greater than $D$. deremensis $\left(0.13 \mu \mathrm{g} \cdot \mathrm{m}^{-3} \cdot \mathrm{cm}^{-2}\right.$ leaf area $)$. Of the herbaceous foliage plants tested, Chlorophytum bichetii, Dieffenbachia 'Marianne', Tillandsia cyanea, Anthurium andraeanum, Syngonium podophyllum, and Peperomia clusiifolia were the most effective in removing formaldehyde, whereas Sansevieria trifasciata, Zamioculcas zamiifolia, and Calathea makoyana were the least (Table 3). Consequently, P. guajava, $R$. excels, Z. pumila, C. bichetii, Dieffenbachia 'Marianne', T. cyanea, and A. andraeanum were in the top $15 \%$ of the 40 woody and herbaceous foliage plants tested (Tables 2 and 3).

Nandina domestica was the most effective of the Korean native plants tested in removing formaldehyde followed by Dendropanax morbifera, Ardisia crenata, Laurus nobilis, Trachelospermum asiaticum, and Stauntonia hexaphyll, whereas Elaeocarpus sylvestris was the least (Table 4). Of the fern species, O. japonica, S. tamariscina, D. mariesii,

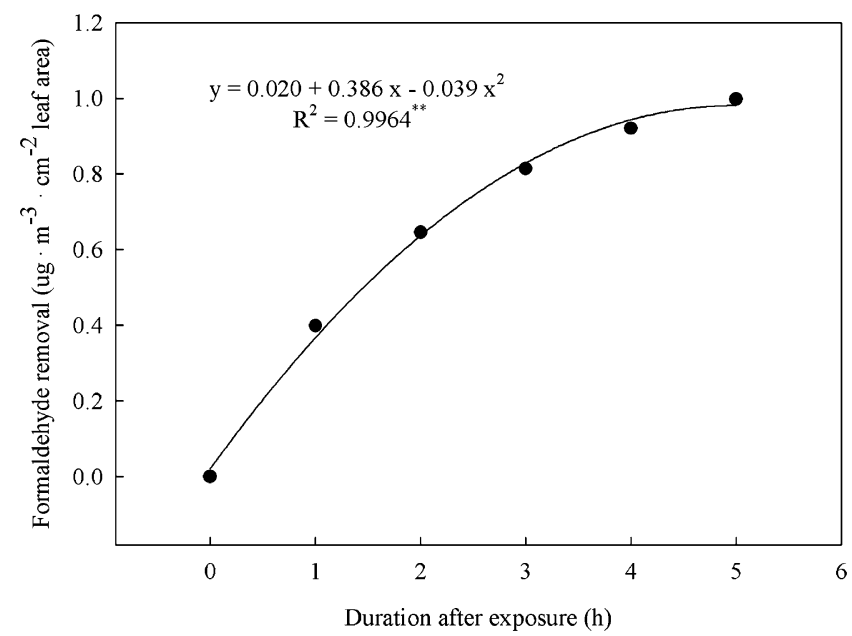

Fig. 2. Mean formaldehyde removal during a 5-h exposure for 86 species of indoor plants (initial concentration $\left.2 \mu \mathrm{L} \cdot \mathrm{L}^{-1}\right)$.

Table 2 . Formaldehyde removal by woody foliage plants when exposed to $2 \mu \mathrm{L} \cdot \mathrm{L}^{-1}$ formaldehyde in sealed chambers for 1 to $5 \mathrm{~h}$.

\begin{tabular}{|c|c|c|c|c|c|}
\hline \multirow[b]{3}{*}{ Scientific name } & \multicolumn{5}{|c|}{ Formaldehyde removal $\left(\mu \mathrm{g} \cdot \mathrm{m}^{-3} \cdot \mathrm{cm}^{-2}\right.$ leaf area $)$} \\
\hline & \multicolumn{5}{|c|}{ Duration after exposure (h) } \\
\hline & 1 & 2 & 3 & 4 & 5 \\
\hline Psidium guajava 'Safeda' & $0.53 \mathrm{ab}^{\mathrm{z}}$ & $1.17 \mathrm{a}$ & $1.69 \mathrm{a}$ & $2.10 \mathrm{a}$ & $2.39 \mathrm{a}$ \\
\hline Rhapis excelsa Wendl. & $0.60 \mathrm{a}$ & $0.88 \mathrm{~b}$ & $1.17 \mathrm{~b}$ & $1.43 \mathrm{~b}$ & $1.67 \mathrm{~b}$ \\
\hline Zamia pumila L. & $0.46 \mathrm{bc}$ & $0.83 \mathrm{~b}$ & $1.09 \mathrm{~b}$ & $1.23 \mathrm{c}$ & $1.32 \mathrm{c}$ \\
\hline Dizygotheca elegantissima R. Vig. \& G. & $0.37 \mathrm{~cd}$ & $0.67 \mathrm{c}$ & $0.87 \mathrm{c}$ & $1.03 \mathrm{~d}$ & $1.13 \mathrm{~d}$ \\
\hline Ficus elastica Roxb. ex Horne. & $0.20 \mathrm{fgh}$ & $0.37 \mathrm{defg}$ & $0.56 \mathrm{de}$ & 0.69 ef & $0.82 \mathrm{e}$ \\
\hline Gardenia jasminoides Ellis & $0.33 \mathrm{de}$ & $0.65 \mathrm{c}$ & $0.75 \mathrm{~cd}$ & $0.79 \mathrm{e}$ & $0.80 \mathrm{e}$ \\
\hline Serissa foetida (L.F) Lam. & $0.24 \mathrm{efg}$ & $0.43 \mathrm{efg}$ & $0.56 \mathrm{de}$ & $0.64 \mathrm{efg}$ & 0.68 ef \\
\hline Eugenia myrtifolia 'Compacta' & $0.32 \mathrm{de}$ & $0.52 \mathrm{~cd}$ & $0.60 \mathrm{de}$ & $0.63 \mathrm{efg}$ & $0.64 \mathrm{f}$ \\
\hline Polyscias balfouriana Bailey & 0.26 ef & $0.45 \mathrm{de}$ & $0.53 \mathrm{e}$ & $0.60 \mathrm{fg}$ & $0.62 \mathrm{f}$ \\
\hline Hedera helix L. & 0.25 ef & 0.42 def & $0.53 \mathrm{e}$ & $0.59 \mathrm{fg}$ & $0.62 \mathrm{f}$ \\
\hline Dracaena concinna Kunth & 0.13 ghij & 0.28 efghi & $0.43 \mathrm{ef}$ & $0.53 \mathrm{fg}$ & $0.61 \mathrm{f}$ \\
\hline Cycas revoluta Thunb. & $0.18 \mathrm{fghi}$ & 0.30 efghi & 0.44 ef & $0.52 \mathrm{fgh}$ & $0.61 \mathrm{f}$ \\
\hline Ficus benjamina L. & 0.19 fghi & 0.32 efgh & 0.44 ef & $0.52 \mathrm{fgh}$ & $0.55 \mathrm{f}$ \\
\hline Cupressus macrocarpa Hartweg 'Gold Crest' & $0.20 \mathrm{fgh}$ & 0.32 efgh & 0.44 ef & $0.49 \mathrm{ghi}$ & $0.52 \mathrm{fg}$ \\
\hline Pachira aquatic Aubl. & 0.12 hij & 0.23 ghij & $0.29 \mathrm{fgh}$ & $0.35 \mathrm{hij}$ & $0.40 \mathrm{gh}$ \\
\hline Hoya cornosa (L.f.) R.Br. & 0.13 ghij $^{z}$ & 0.20 hij & $0.27 \mathrm{fgh}$ & $0.33 \mathrm{ij}$ & $0.37 \mathrm{gh}$ \\
\hline Araucaria heterophylla Franco & $0.19 \mathrm{fghi}$ & 0.28 efghi & $0.33 \mathrm{fg}$ & $0.35 \mathrm{ij}$ & $0.35 \mathrm{~h}$ \\
\hline Schefflera arboricola Hayata 'Hong Kong' & 0.15 fghij & 0.27 fghij & $0.29 \mathrm{fgh}$ & $0.29 \mathrm{jk}$ & $0.29 \mathrm{hi}$ \\
\hline Dracaena fragrans Ker. 'Massangeana' & $0.08 \mathrm{ij}$ & $0.14 \mathrm{ij}$ & $0.16 \mathrm{gh}$ & $0.17 \mathrm{kl}$ & $0.17 \mathrm{ij}$ \\
\hline Dracaena deremensis N.E. Br. 'Warneckii' & $0.07 \mathrm{j}$ & $0.13 \mathrm{j}$ & $0.13 \mathrm{~h}$ & 0.131 & $0.13 \mathrm{j}$ \\
\hline
\end{tabular}

${ }^{\mathrm{z}}$ Mean separation with columns by least significant difference test at $\alpha \leq 0.05$.

Table 3. Formaldehyde removal by herbaceous foliage plants when exposed to $2 \mu \mathrm{L} \cdot \mathrm{L}^{-1}$ formaldehyde in sealed chambers for 1 to $5 \mathrm{~h}$.

\begin{tabular}{|c|c|c|c|c|c|}
\hline \multirow[b]{3}{*}{ Scientific name } & \multicolumn{5}{|c|}{ Formaldehyde removal $\left(\mu \mathrm{g} \cdot \mathrm{m}^{-3} \cdot \mathrm{cm}^{-2}\right.$ leaf area $)$} \\
\hline & \multicolumn{5}{|c|}{ Duration after exposure $(\mathrm{h})$} \\
\hline & 1 & 2 & 3 & 4 & 5 \\
\hline Chlorophytum bichetii Baker & $0.29 \mathrm{de}$ & $0.55 \mathrm{~cd}$ & $0.85 \mathrm{ab}$ & $1.05 \mathrm{a}$ & $1.25 \mathrm{a}$ \\
\hline Dieffenbachia amoena 'Marianne' & $0.36 \mathrm{~cd}$ & $0.68 \mathrm{ab}$ & $0.88 \mathrm{ab}$ & $1.08 \mathrm{a}$ & $1.24 \mathrm{a}$ \\
\hline Tillandsia cyanea Linden ex C. Koch & $0.48 \mathrm{a}$ & $0.73 \mathrm{a}$ & $0.95 \mathrm{a}$ & $1.11 \mathrm{a}$ & $1.23 \mathrm{a}$ \\
\hline Anthurium andraeanum Linden & $0.32 \mathrm{~cd}$ & $0.61 \mathrm{bc}$ & $0.90 \mathrm{ab}$ & $1.06 \mathrm{a}$ & $1.22 \mathrm{a}$ \\
\hline Syngonium podophyllum Schott & 0.23 ef & $0.49 \mathrm{de}$ & $0.74 \mathrm{~cd}$ & $0.93 \mathrm{~b}$ & $1.06 \mathrm{~b}$ \\
\hline Peperomia clusiifolia Hook. & $0.43 \mathrm{ab}$ & $0.62 \mathrm{bc}$ & $0.79 \mathrm{bc}$ & $0.89 \mathrm{bc}$ & $0.94 \mathrm{bc}$ \\
\hline Haemaria discolor Lindl. & $0.34 \mathrm{~cd}$ & $0.59 \mathrm{~cd}$ & 0.70 cde & $0.80 \mathrm{~cd}$ & $0.85 \mathrm{~cd}$ \\
\hline Asplenium nidus L. 'avis' & $0.35 \mathrm{~cd}$ & 0.53 cde & 0.69 cde & $0.76 \mathrm{~cd}$ & $0.83 \mathrm{~cd}$ \\
\hline Saintpaulia ionantha $\mathrm{H}$. Wendl & 0.24 ef & 0.44 ef & $0.60 \mathrm{e}$ & $0.72 \mathrm{~d}$ & $0.81 \mathrm{~cd}$ \\
\hline Aglaonema modestum & $0.30 \mathrm{cde}$ & $0.50 \mathrm{de}$ & $0.65 \mathrm{de}$ & $0.75 \mathrm{~d}$ & $0.78 \mathrm{~d}$ \\
\hline Philodendron selloum C. Koch. & $0.37 \mathrm{bc}^{\mathrm{z}}$ & $0.53 \mathrm{cde}$ & $0.64 \mathrm{de}$ & $0.70 \mathrm{~d}$ & $0.76 \mathrm{~d}$ \\
\hline Chrysalidocarpus lutescens $\mathrm{H}$. Wendl & $0.21 \mathrm{f}$ & $0.37 \mathrm{fg}$ & $0.47 \mathrm{f}$ & $0.55 \mathrm{e}$ & $0.61 \mathrm{e}$ \\
\hline Howea belmoreana Becc. & $0.22 \mathrm{f}$ & $0.31 \mathrm{gh}$ & $0.43 \mathrm{f}$ & $0.49 \mathrm{e}$ & $0.53 \mathrm{e}$ \\
\hline Phoenix roebelenii O'Brien. & $0.21 \mathrm{f}$ & $0.34 \mathrm{~g}$ & $0.42 \mathrm{f}$ & $0.48 \mathrm{e}$ & $0.51 \mathrm{e}$ \\
\hline Epipremnum aureum Bunt. & $0.21 \mathrm{f}$ & $0.34 \mathrm{~g}$ & $0.40 \mathrm{~g}$ & $0.44 \mathrm{f}$ & 0.44 ef \\
\hline Spathiphyllum wallisii Regal & $0.13 \mathrm{gh}$ & $0.21 \mathrm{ij}$ & $0.28 \mathrm{~g}$ & $0.31 \mathrm{f}$ & $0.37 \mathrm{f}$ \\
\hline Clivia miniata Regal & $0.14 \mathrm{gh}$ & $0.24 \mathrm{hi}$ & $0.30 \mathrm{~g}$ & $0.33 \mathrm{f}$ & $0.34 \mathrm{fg}$ \\
\hline Calathea makoyana E. Morr. & $0.12 \mathrm{gh}$ & $0.20 \mathrm{ij}$ & $0.26 \mathrm{~g}$ & $0.27 \mathrm{f}$ & $0.29 \mathrm{fg}$ \\
\hline Zamioculcas zamiifolia & $0.12 \mathrm{gh}$ & $0.19 \mathrm{ij}$ & $0.24 \mathrm{~g}$ & $0.27 \mathrm{f}$ & $0.29 \mathrm{fg}$ \\
\hline Sansevieria trifasciata Prain & $0.08 \mathrm{~h}$ & $0.14 \mathrm{j}$ & $0.18 \mathrm{~g}$ & $0.21 \mathrm{f}$ & $0.23 \mathrm{fg}$ \\
\hline
\end{tabular}

${ }^{\mathrm{z}}$ Mean separation with columns by least significant difference test at $\alpha \leq 0.05$. 
Polypodium formosanum, $P$. dispar, and $P$. multifida were highly effective in removing formaldehyde (Table 5). For example, $O$. japonica removed $6.64 \mu \mathrm{g} \cdot \mathrm{m}^{-3}$ of formaldehyde $/ \mathrm{cm}^{2}$ of leaf area over $5 \mathrm{~h}$ and was the most effective of the 86 species tested. In contrast, $D$. deremensis was the least effective. Of the herbs, Lavandula spp., Pelargonium spp., and Rosmarinus officinalis were the most effective in removing formaldehyde (Table 6).

Wolverton (1997) reported that Nephrolepis exaltata, Chrysanthemum morifolium, Gerbera jamesonii, Phoenix roebelenii, $D$. deremensis, Chamaedorea seifrizii, and Nephrolepis obliterate ranked highest among 50 test species in removing formaldehyde with the ferns $N$. exaltata and $N$. obliterate being in the top $15 \%$ of the plants tested. Although we also found the ferns to effectively remove formaldehyde, there were distinct differences between tests. Wolverton (1986) found that with exposure to $10 \mu \mathrm{L} \cdot \mathrm{L}^{-1}$ formaldehyde for $6 \mathrm{~h}$, Philodendron, Chlorophytum elatum, Aloe vera, and Scindapsus aureus removed greater than $2.2 \mu \mathrm{g} \cdot \mathrm{m}^{-3} \cdot \mathrm{cm}^{-2}$ leaf area, whereas $S$. wallisii and $S$. trifasciata removed relatively little formaldehyde $\left(1.05\right.$ and $0.76 \mu \mathrm{g} \cdot \mathrm{m}^{-3} \cdot \mathrm{cm}^{-2}$ leaf area, respectively). Our results were lower for $S$. wallisii $\left(0.37 \mu \mathrm{g} \cdot \mathrm{m}^{-3} \cdot \mathrm{cm}^{-2}\right.$ leaf area) and $S$. trifasciata $\left(0.23 \mu \mathrm{g} \cdot \mathrm{m}^{-3} \cdot \mathrm{cm}^{-2}\right.$ leaf area) (Table 3), which appeared to be the result of the significantly lower initial formaldehyde concentration (10 versus $\left.2 \mu \mathrm{L} \cdot \mathrm{L}^{-1}\right)$ and to a lesser extent the shorter time interval (6 versus $5 \mathrm{~h}$ ).

When comparing the five general classes of plants, ferns were the most effective in removing formaldehyde followed by herbs (Fig. 3 ). There were major differences in formaldehyde removal efficiency among species within the ferns as indicated by the high SE values. There were no significant differences between the woody and herbaceous foliage plants and the Korean native plants classes in the removal of formaldehyde. Figure 4 illustrates formaldehyde removal by the 86 species based on a total leaf area per chamber. Formaldehyde removal decreased slightly with increasing total leaf area in the chamber. Although formaldehyde is absorbed and metabolized by both the leaves and the rhizosphere microorganisms (Godish and Guindon, 1989; Kim et al., 2008; Wolverton et al., 1989; Wood et al., 2002), the efficiency of formaldehyde removal is generally expressed on a unit leaf area basis (Kim and Lee, 2008; Orwell et al., 2006; Wolverton et al., 1989; Wood et al., 2002; Yoo et al., 2006). Thus, the calculated efficiency of formaldehyde removal was lower at higher total leaf areas in the chamber when comparing different sizes of plants with the same media volume (Kim and Kim, 2008) because the effect of rhizosphere microorganisms is not considered in calculating the efficiency.

Differences in ranking between Wolverton's data (Wolverton, 1986, 1997) and the current study appear to be largely the result of differences in methods (e.g., concentration, test chambers, cultivars). The test concentration of formaldehyde is known to be critical because the rate of $\mathrm{VOC}$ removal decreases as the internal concentration declines (Kim et al.,

Table 4. Formaldehyde removal by Korean native plants when exposed to $2 \mu \mathrm{L} \cdot \mathrm{L}^{-1}$ formaldehyde in sealed chambers for 1 to $5 \mathrm{~h}$.

\begin{tabular}{|c|c|c|c|c|c|}
\hline \multirow[b]{3}{*}{ Scientific name } & \multicolumn{5}{|c|}{ Formaldehyde removal $\left(\mu \mathrm{g} \cdot \mathrm{m}^{-3} \cdot \mathrm{cm}^{-2}\right.$ leaf area $)$} \\
\hline & \multicolumn{5}{|c|}{ Duration after exposure $(\mathrm{h})$} \\
\hline & 1 & 2 & 3 & 4 & 5 \\
\hline Nandina domestica Thunb. & 0.28 defg & $0.72 \mathrm{bc}$ & $1.05 \mathrm{~b}$ & $1.35 \mathrm{a}$ & $1.58 \mathrm{a}$ \\
\hline Dendropanax morbifera Nakai & 0.34 cdef & $0.70 \mathrm{c}$ & $1.03 \mathrm{~b}$ & $1.30 \mathrm{a}$ & $1.50 \mathrm{ab}$ \\
\hline Ardisia crenata Sims. & $0.62 \mathrm{a}$ & $1.04 \mathrm{a}$ & $1.27 \mathrm{a}$ & $1.40 \mathrm{a}$ & $1.46 \mathrm{ab}$ \\
\hline Laurus nobilis L. & $0.45 \mathrm{~b}$ & $0.83 \mathrm{~b}$ & $1.11 \mathrm{~b}$ & $1.28 \mathrm{a}$ & $1.40 \mathrm{ab}$ \\
\hline Trachelospermum asiaticum Nakai & $0.28 \mathrm{defg}$ & $0.54 \mathrm{~d}$ & $0.81 \mathrm{c}$ & $0.92 \mathrm{~b}$ & $1.03 \mathrm{c}$ \\
\hline Stauntonia hexaphylla (Thunb.) Dence. & $0.08 \mathrm{j}$ & $0.25 \mathrm{hi}$ & 0.40 efgh & 0.54 cde & $0.66 \mathrm{~d}$ \\
\hline Raphiolepis umbellata Makino & $0.42 \mathrm{bc}$ & $0.56 \mathrm{~d}$ & $0.59 \mathrm{~d}$ & $0.59 \mathrm{c}$ & 0.59 de \\
\hline Viburnum awabuki K. Koch & $0.46 \mathrm{~b}$ & $0.55 \mathrm{~d}$ & $0.55 \mathrm{de}$ & 0.55 cde & $0.55 \mathrm{def}$ \\
\hline Quercus glauca Thunb. & 0.36 cde & $0.52 \mathrm{def}$ & $0.55 \mathrm{de}$ & 0.55 cde & $0.55 \mathrm{def}$ \\
\hline Ilex crenata Thunb. & $0.36 \mathrm{cde}$ & $0.46 \mathrm{efg}$ & 0.50 def & $0.51 \mathrm{cdef}$ & 0.51 defg \\
\hline Chamaecyparis obtusa Endl. & $0.26 \mathrm{efgh}$ & $0.38 \mathrm{fgh}$ & 0.43 efgh & 0.47 cdefg & 0.50 defg \\
\hline Fatsia japonica Decne. et Planch. & $0.22 \mathrm{ghi}^{\mathrm{z}}$ & $0.36 \mathrm{fgh}$ & $0.44 \mathrm{defg}$ & 0.48 cdefg & 0.50 defg \\
\hline Eurya emarginata (Thunb.) Makino & $0.28 \mathrm{defg}$ & $0.42 \mathrm{efg}$ & 0.46 defg & 0.46 cdefg & $0.47 \mathrm{efg}$ \\
\hline Pittosporum tobira Ait. & 0.25 efgh & $0.34 \mathrm{fgh}$ & $0.39 \mathrm{fg}$ & $0.41 \mathrm{de}$ & $0.44 \mathrm{ef}$ \\
\hline Camellia sinensis Kuntz. & $0.16 \mathrm{hij}$ & $0.29 \mathrm{ghi}$ & 0.36 fghi & 0.40 defg & $0.43 \mathrm{fg}$ \\
\hline Ardisia pusilla DC. & $0.14 \mathrm{ij}$ & $0.26 \mathrm{hi}$ & $0.33 \mathrm{ghi}$ & $0.38 \mathrm{efgh}$ & $0.43 \mathrm{fg}$ \\
\hline Ligustrum japonicum Thunb. & $0.28 \mathrm{defg}$ & $0.35 \mathrm{fgh}$ & 0.36 fghi & $0.36 \mathrm{fgh}$ & $0.36 \mathrm{gh}$ \\
\hline Quercus acuta Thunb. & $0.26 \mathrm{efgh}$ & $0.32 \mathrm{fgh}$ & 0.36 fghi & $0.36 \mathrm{fgh}$ & $0.36 \mathrm{gh}$ \\
\hline Camellia japonica $\mathrm{L}$ & $0.16 \mathrm{hij}$ & $0.26 \mathrm{hi}$ & $0.30 \mathrm{hi}$ & $0.32 \mathrm{gh}$ & $0.33 \mathrm{gh}$ \\
\hline Elaeocarpus sylvestris Hara 'ellipticus' & $0.14 \mathrm{ij}$ & $0.19 \mathrm{i}$ & $0.21 \mathrm{i}$ & $0.22 \mathrm{~h}$ & $0.23 \mathrm{~h}$ \\
\hline
\end{tabular}

${ }^{\mathrm{z}}$ Mean separation with columns by least significant difference test at $\alpha \leq 0.05$.

Table 5 . Formaldehyde removal by ferns when exposed to $2 \mu \mathrm{L} \cdot \mathrm{L}^{-1}$ formaldehyde in sealed chambers for 1 to $5 \mathrm{~h}$.

\begin{tabular}{|c|c|c|c|c|c|}
\hline \multirow[b]{3}{*}{ Scientific name } & \multicolumn{5}{|c|}{ Formaldehyde removal $\left(\mu \mathrm{g} \cdot \mathrm{m}^{-3} \cdot \mathrm{cm}^{-2}\right.$ leaf area $)$} \\
\hline & \multicolumn{5}{|c|}{ Duration after exposure $(\mathrm{h})$} \\
\hline & 1 & 2 & 3 & 4 & 5 \\
\hline Osmunda japonica Thunb. & $2.82 \mathrm{a}^{\mathrm{z}}$ & $4.42 \mathrm{a}$ & $5.42 \mathrm{a}$ & $6.19 \mathrm{a}$ & $6.64 \mathrm{a}$ \\
\hline Selaginella tamariscina Spring & $2.22 \mathrm{~b}$ & $3.48 \mathrm{~b}$ & $4.16 \mathrm{~b}$ & $4.60 \mathrm{~b}$ & $4.84 \mathrm{~b}$ \\
\hline Davallia mariesii Moore ex Baker & $1.34 \mathrm{c}$ & $2.37 \mathrm{c}$ & $3.16 \mathrm{c}$ & $3.74 \mathrm{c}$ & $4.15 \mathrm{c}$ \\
\hline Polypodium formosanum Baker & $1.20 \mathrm{c}$ & $2.09 \mathrm{c}$ & $2.69 \mathrm{~d}$ & $3.21 \mathrm{~d}$ & $3.62 \mathrm{c}$ \\
\hline Pteris dispar kunze. & $0.89 \mathrm{~d}$ & $1.40 \mathrm{~d}$ & $1.70 \mathrm{e}$ & $1.86 \mathrm{e}$ & $1.95 \mathrm{~d}$ \\
\hline Pteris multifida Poir. & $0.82 \mathrm{de}$ & $1.34 \mathrm{~d}$ & $1.64 \mathrm{e}$ & $1.76 \mathrm{e}$ & $1.92 \mathrm{~d}$ \\
\hline Microlepia strigosa (Thunb.) Presl. & $0.66 \mathrm{def}$ & $1.07 \mathrm{de}$ & 1.29 ef & $1.42 \mathrm{ef}$ & $1.49 \mathrm{de}$ \\
\hline Botrychium ternatum (Thunb.) Swartz. & $0.68 \mathrm{def}$ & $1.06 \mathrm{de}$ & $1.26 \mathrm{ef}$ & $1.38 \mathrm{ef}$ & $1.42 \mathrm{def}$ \\
\hline Cyrtomium caryotideum Nakai 'coreanum' & 0.59 efg & $0.78 \mathrm{ef}$ & $0.92 \mathrm{fg}$ & $1.00 \mathrm{fgh}$ & $1.09 \mathrm{efg}$ \\
\hline Pteris ensiformis Burm. 'victoriae' & $0.53 \mathrm{fgh}$ & 0.78 ef & $0.91 \mathrm{fg}$ & $0.97 \mathrm{fgh}$ & $1.01 \mathrm{efgh}$ \\
\hline Polystichum tripteron (Kunze.) Presl. & 0.36 ghi & $0.61 \mathrm{fg}$ & $0.78 \mathrm{gh}$ & $0.88 \mathrm{ghi}$ & $0.92 \mathrm{efgh}$ \\
\hline Dryopteris nipponensis Koidz. & 0.43 fghi & $0.64 \mathrm{fg}$ & $0.76 \mathrm{gh}$ & 0.85 ghi & 0.91 efgh \\
\hline Adiantum capillusveneris L. & $0.35 \mathrm{ghi}$ & $0.58 \mathrm{fg}$ & $0.72 \mathrm{gh}$ & $0.81 \mathrm{hi}$ & $0.86 \mathrm{fgh}$ \\
\hline Thelypteris esquirolii K. Iwats. 'glabrata' & 0.43 fghi & $0.66 \mathrm{fg}$ & $0.77 \mathrm{gh}$ & $0.82 \mathrm{hi}$ & 0.84 fgh \\
\hline Coniogramme japonica (Thunb.) Diels & 0.44 fghi & $0.61 \mathrm{fg}$ & $0.70 \mathrm{gh}$ & $0.74 \mathrm{hi}$ & $0.76 \mathrm{gh}$ \\
\hline Cyrtomium falcatum (L.f.) Presl. & $0.39 \mathrm{ghi}$ & $0.58 \mathrm{fg}$ & $0.67 \mathrm{gh}$ & $0.67 \mathrm{hi}$ & $0.67 \mathrm{gh}$ \\
\hline Thelypteris acuminate (Houtt.) Morton & $0.33 \mathrm{hi}$ & $0.46 \mathrm{fg}$ & $0.49 \mathrm{gh}$ & $0.50 \mathrm{hi}$ & $0.51 \mathrm{gh}$ \\
\hline Arachniodes aristata (G. Forst.) Tindale & $0.30 \mathrm{hi}$ & $0.27 \mathrm{~g}$ & $0.47 \mathrm{gh}$ & $0.49 \mathrm{hi}$ & $0.49 \mathrm{gh}$ \\
\hline Thelypteris decursivepinnata Ching & $0.27 \mathrm{hi}$ & $0.41 \mathrm{fg}$ & $0.45 \mathrm{gh}$ & $0.47 \mathrm{hi}$ & $0.47 \mathrm{gh}$ \\
\hline Thelypteris torresiana K. Iwats. 'calvata' & $0.24 \mathrm{i}$ & $0.33 \mathrm{~g}$ & $0.37 \mathrm{~h}$ & $0.39 \mathrm{i}$ & $0.40 \mathrm{~h}$ \\
\hline
\end{tabular}

${ }^{\mathrm{z}}$ Mean separation with columns by least significant difference test at $\alpha \leq 0.05$.

Table 6 . Formaldehyde removal by herbs when exposed to $2 \mu \mathrm{L} \cdot \mathrm{L}^{-1}$ formaldehyde in sealed chambers for 1 to $5 \mathrm{~h}$.

\begin{tabular}{lccccc}
\hline & \multicolumn{5}{c}{ Formaldehyde removal $\left(\mu \mathrm{g} \cdot \mathrm{m}^{-3} \cdot \mathrm{cm}^{-2}\right.$ leaf area $)$} \\
\cline { 2 - 6 } & \multicolumn{5}{c}{ Duration after exposure $(\mathrm{h})$} \\
\cline { 2 - 6 } Scientific name & 1 & 2 & 3 & 4 & 5 \\
\hline Lavandula spp. & $1.35 \mathrm{a}^{\mathrm{z}}$ & $1.80 \mathrm{a}$ & $1.97 \mathrm{a}$ & $2.06 \mathrm{a}$ & $2.12 \mathrm{a}$ \\
Pelargonium spp. & $0.58 \mathrm{~b}$ & $1.00 \mathrm{~b}$ & $1.44 \mathrm{~b}$ & $1.66 \mathrm{~b}$ & $1.87 \mathrm{~b}$ \\
Rosmarinus officinalis L. & $0.75 \mathrm{~b}$ & $0.96 \mathrm{~b}$ & $1.03 \mathrm{~b}$ & $1.05 \mathrm{~b}$ & $1.05 \mathrm{~b}$ \\
Mentha guaveolens 'applemint' & $0.22 \mathrm{c}$ & $0.41 \mathrm{c}$ & $0.61 \mathrm{~cd}$ & $0.73 \mathrm{c}$ & $0.89 \mathrm{c}$ \\
Jasminum polyanthum Franchet & $0.29 \mathrm{c}$ & $0.53 \mathrm{c}$ & $0.70 \mathrm{c}$ & $0.78 \mathrm{c}$ & $0.84 \mathrm{c}$ \\
Jasminum sambac (L.) Aiton & $0.18 \mathrm{c}$ & $0.30 \mathrm{c}$ & $0.36 \mathrm{~d}$ & $0.38 \mathrm{~d}$ & $0.42 \mathrm{~d}$ \\
\hline
\end{tabular}

${ }^{\mathrm{z}}$ Mean separation with columns by least significant difference test at $\alpha \leq 0.05$.

2008). Wolverton (1986) used various initial formaldehyde concentrations ranging from $1 \mu \mathrm{L} \cdot \mathrm{L}^{-1}$ to $22 \mu \mathrm{L} \cdot \mathrm{L}^{-1}$. The current results are based on an initial formaldehyde concentration of $2 \mu \mathrm{L} \cdot \mathrm{L}^{-1}$, which was selected based on the maximum acceptable concentration in homes and offices (Ministry of Environment, Republic of Korea, 2006) and was used over the entire 5-year test period for each of the 86 species. 


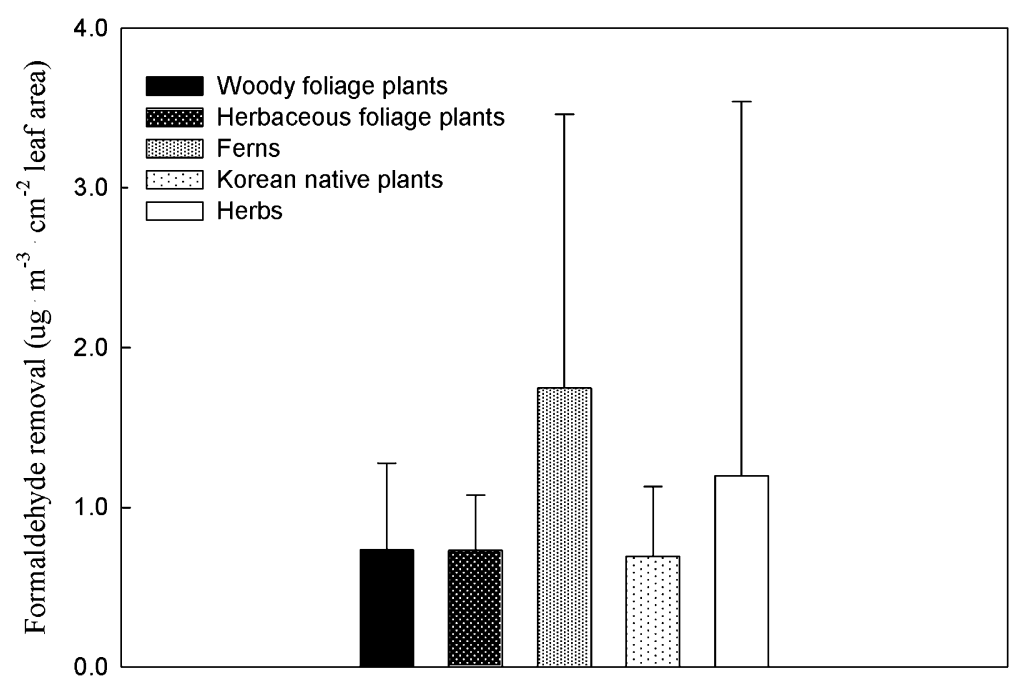

Pot plant groups

Fig. 3. Mean formaldehyde removal by indoor plants, grouped into five general categories based on the type of plant when exposed to $2 \mu \mathrm{L} \cdot \mathrm{L}^{-1}$ formaldehyde for $5 \mathrm{~h}$. Vertical bars (SE) denote variation among species within groups.

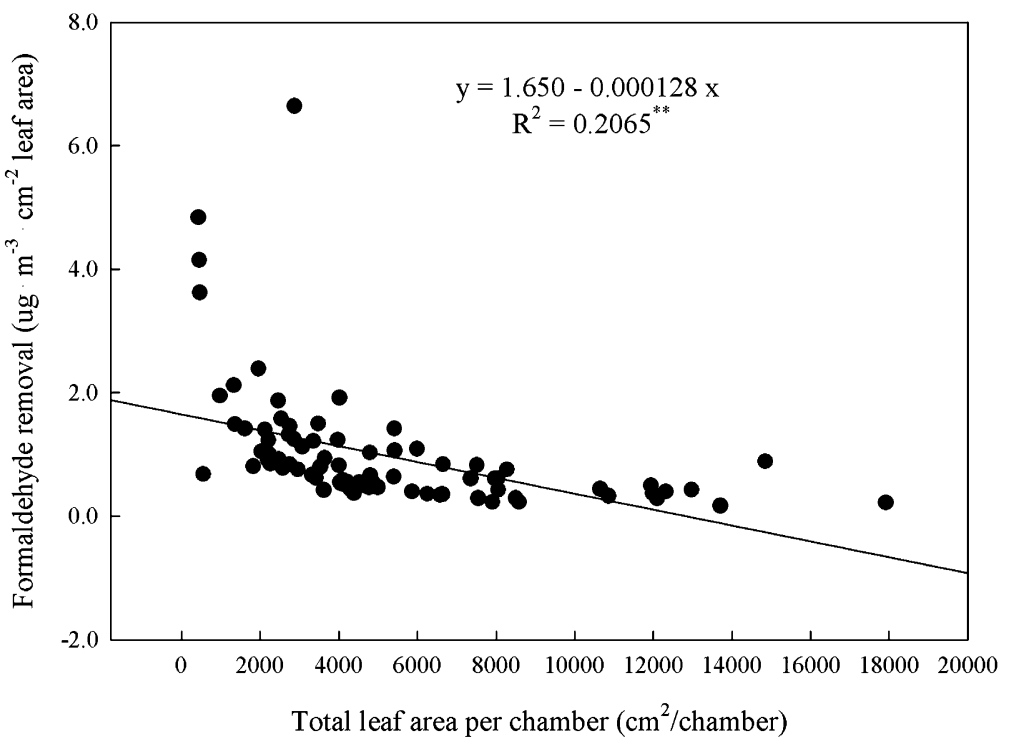

Fig. 4. The effect of total leaf area per chamber for 86 indoor species on the efficiency of formaldehyde removal during a 5 -h exposure (initial concentration $2 \mu \mathrm{L} \cdot \mathrm{L}^{-1}$ ).

The most effective species for removing formaldehyde, $O$. japonica, was 50 times more effective than the least $(D$. deremensis) indicating the extensive range found among the plants. Based on this diversity, we separated the species into three general groups based on formaldehyde removal efficiency: excellent (greater than $1.2 \mu \mathrm{g} \cdot \mathrm{m}^{-3}$ formaldehyde per $\mathrm{cm}^{2}$ of leaf area over $\left.5 \mathrm{~h}\right)$, intermediate $(1.2$ or less to 0.6 ), and poor (less than 0.6). The species classified as excellent are considered desirable for use in homes and offices where the formaldehyde concentration in the air is of concern. The species tested were predominantly indoor ornamentals. However, there are likely other species within the plant kingdom that may be equal or more effective than $O$. japonica. A better understanding of the effect of concentration, duration of exposure, and presence of other VOCs (Yang et al., 2009) on the health and VOC removal efficiency of interior plants needs to be ascertained. It is evident from our results that certain species have the potential to improve interior environments and, in so doing, the health and well-being of the inhabitants.

\section{Literature Cited}

Darlington, A., M. Chan, D. Malloch, C. Pilger, and M.A. Dixon. 2000. The biofiltration of indoor air: Implications for air. Indoor Air 10:39-46.

Darlington, A.B., M.A. Dixon, and C. Pilger. 1998. The use of biofilters to improve indoor air quality: The removal of toluene, TCE and formaldehyde. Life Support Biosph. Sci. 5:63-69.

Giese, M., U. Bauer-Doranth, C. Langebartels, and H. Sandermann. 1994. Detoxification of formaldehyde by the spider plant (Chlorophytum comosum L.) and by soybean (Glycine $\max$ L.) cell-suspension cultures. Plant Physiol. 104: 1301-1309.

Godish, T. and C. Guindon. 1989. An assessment of botanical air purification as a formaldehyde mitigation measure under dynamic laboratory chamber conditions. Environ. Pollut. 61:1320.

Hanson, A.D. and S. Roje. 2001. One-carbon metabolism in higher plants. Annu. Rev. Plant Physiol. Plant Mol. Biol. 52:119-137.

Hines, A.L., T.K. Ghosh, S.K. Loylka, and R.C. Warder, Jr. 1993. Indoor air: Quality and control. Prentice Hall, Englewood Cliffs, NJ

Jones, A.P. 1999. Indoor air quality and health. Atmos. Environ. 33:4535-4564.

Kempeneer, L.D., B. Sercu, W. Vanbrabant, H.V. Langenhove, and W. Verstraete. 2004. Bioaugmentation of the phyllosphere for the removal of toluene from indoor air. Appl. Microbiol. Biotechnol. 64:284-288.

Kil, M.J., K.J. Kim, C.H. Pak, H.H. Kim, and Y.W. Lim. 2008a. Effects of growing media and exposure frequency on the volatile formaldehyde removal in potted Epipremnum aureum. Kor. J. Hort. Sci. Technol. 26:325-330.

Kil, M.J., K.J. Kim, J.K. Gho, and C.H. Pak. 2008 b. Formaldehyde gas removal effects and physiological responses of Fatsia japonica and Epipremnum aureum according to various light intensity. Kor. J. Hort. Sci. Technol. 26: 189-196.

Kim, K.J., M.J. Kil, M.I. Jeong, H.D. Kim, E.H Yoo, S.J. Jeong, C.H. Pak, and K.C. Son. 2009. Determination of the efficiency of formaldehyde removal according to the percentage volume of pot plants occupying a room. Kor. J. Hort. Sci. Technol. 27:305-311.

Kim, K.J., M.J. Kil, J.S. Song, E.H. Yoo, K.C. Son, and S.J. Kays. 2008. Efficiency of volatile formaldehyde removal by indoor plants Contribution of aerial plant parts versus the root zone. J. Amer. Soc. Hort. Sci. 133:521526.

Kim, K.J. and H.D. Kim. 2008. Development of model and calculating equation for rate of volatile formaldehyde removal of indoor plants. Hort. Environ. Biotechnol. 49:155-161.

Kim, K.J. and D.W. Lee. 2008. Efficiency of volatile formaldehyde removal of orchids as affected by species and crassulacean acid metabolism (CAM) nature. Hort. Environ. Biotechnol. 49:123-137.

Kostiaineh, R. 1995. Volatile organic compounds in the indoor air of normal and sick houses. Atmos. Environ. 29:693-702.

Kraffczyk, I., G. Trolldenier, and H. Beringer. 1984. Soluble root exudates of maize influence of potassium supply and rhizosphere microorganisms. Soil Biol. Biochem. 16:315322

Marco, M., B. Seifert, and T. Lindvall. 1995. Indoor air quality: A comprehensive reference book. Air quality monographs. Academic Press, New York, NY.

Mercier, J. and S.E. Lindow. 2000. Role of leaf surface sugars in colonization of plants by bacterial epiphytes. Appl. Environ. Microbiol. 66:369-374.

Ministry of Environment, Republic of Korea. 2006. Republic of Korea's enforcement ordinance on indoor air quality management. Ministry of Environment, Seoul, Korea.

Orwell, R.L., R.A. Wood, M.D. Burchett, J. Tarran, and F. Torpy. 2006. The potted-plant microcosm substantially reduces indoor air VOC pollution: II. Laboratory study. Water Air Soil Pollut. 177:59-80.

HortScience Vol. 45(10) October 2010 
Oyabu, T., A. Sawada, T. Onodera, K. Takenaka, and B. Worverton. 2003. Characteristics of potted plants for removing offensive odors. Sens. Actuators B Chem. 89:131-136.

Salt, D.E., R.D. Smith, and I. Raskin. 1998. Phytoremediation. Annu. Rev. Plant Physiol. Plant Mol. Biol. 49:643-668.

Salthammer, T. 1999. Organic indoor air pollutant: Occurrence-measurement-evaluation. Wiley, New York, NY.

Schmitz, H. 1995. Bakterielle und pflazliche entgiftungs mechamismen fuer formaldehyde und nikotin under rhizosphare von Epipremnum aureum und Ficus benjamina. $\mathrm{PhD}$ thesis, University of Köln, Köln, Germany.

Schwab, A.P., A.A. Al-Assi, and M.K. Banks. 1998. Adsorption of naphthalene onto plant roots. J. Environ. Qual. 27:220-224.

Shinohara, N., A. Mizukoshi, and Y. Yangisawa 2004. Identification of responsible volatile chemicals that induce hypersensitive reactions to multiple chemical sensitivity patients. J. Expo. Anal. Environ. Epidemiol. 14:84-91.

Spengler, J.D. and K. Sexton. 1983. Indoor air pollution: A public health perspective. Science 221:9-16.

Ugrekhelidze, D., F. Korte, and G. Kvesitadze. 1997. Uptake and transformation of benzene and toluene by plant leaves. Ecotoxicol. Environ. Saf. 6:24-29.

WHO. 2002. World health report 2002. World Health Organization. <http://www.who.int/whr/ 2002/en/whr02_en.pdf>.

Wolverton, B.C. 1986. Houseplants, indoor air pollutants, and allergic reactions. Rept. National Aeronautics Space Administration, Stennis Space Center, MS.

Wolverton, B.C. 1997. How to grow fresh air: Houseplants that purify your home or office. Penguin Books, Harmondsworth Middlesex, UK, p. 23.
Wolverton, B.C., A. Johnson, and K. Bounds. 1989. Interior landscape plants for indoor air pollution abatement. Final Rept. National Aeronautics Space Administration, Stennis Space Center, MS.

Wood, R.A., R.L. Orwell, J. Tarran, F. Torpy, and M. Burchett. 2002. Potted-plant/growth media interactions and capacities for removal of volatiles from indoor air. J. Hort. Sci. Biotechnol. 77:120-129.

Yang, D.S., S.V. Pennisi, K.C. Son, and S.J. Kays. 2009. Screening indoor plants for volatile organic pollutant removal efficiency. HortScience 44:1377-1381.

Yoo, M.H., Y.J. Kwon, K.C. Son, and S.J. Kays. 2006. Efficacy of indoor plants for the removal of single and mixed volatile organic pollutants and physiological effects of the volatiles on the plants. J. Amer. Soc. Hort. Sci. 131:452458 